\title{
A plan of action to turn down the inevitability of death through cancer in Africa
}

\author{
Au front pour le refus de la fatalité du cancer en Afrique
}

\author{
A. Ly \\ C) Springer-Verlag France 2013
}

The enthusiasm seen at the beginning has continued to grow throughout the short five year life of the Journal Africain $d u$ Cancer/African Journal of Cancer (JAC). It is with continued excitement and plenty of hope for the future that we are celebrating both this the $20^{\text {th }}$ edition and also the $5^{\text {th }}$ volume of the journal. It would be difficult to rationalize these great feelings. We will, nevertheless, attempt to do this. There are several explanations for this.

The Millennium Development Goals (MDGs) should be achieved in 2015, which is still several months away. However, it is clear that a number of countries, especially those in Sub-Saharan Africa, are not going to reach them [1-3]. Indeed, these countries, which are among the most vulnerable in the world, are faced with an ever increasing number of healthcare priorities. In addition to non-communicable diseases, there are also infant and maternal, parasitical and transmissible diseases. Of these chronic conditions, cancer is a significant burden [4]. In 2008, it was responsible for 541,800 deaths. The incidence of cancer is also seeing regular increases and it currently stands at 715,600 new cases, including 325,000 in men and 390,000 in women [4-6].

The epidemiological profile is characterized by a very high mortality rate ( $78 \%$ of cases) and the disease being detected far too late, thus ruling out any treatment possibilities. Nevertheless, chronic infections are among the most common and most avoidable aetiological factors (AIDS, hepatitis $\mathrm{B}$ and $\mathrm{C}$, chronic gastrointestinal inflammation, etc.). They cause approximately $30 \%$ of all cases of malignant tumours [5-7].

What can be said about the epidemiological outlook for cancer in Africa? A worsening in the current situation, which may result in a doubling in both the incidence and mortality,

A. Ly $(\bowtie)$

Afrocancer, BP 60751, F-75827 Paris cedex 17, France

e-mail : adamaly@gmail.com
L'enthousiasme des débuts n'a pas faibli au cours des cinq années de la jeune existence du Journal Africain du Cancer/ African Journal of Cancer (JAC). C'est sans émotion retenue et plein d'espoirs pour l'avenir que nous célébrons le bouclage à la fois de ce $20^{e}$ numéro et de ce $5^{e}$ volume. Il serait difficile de rationnaliser ces états de plénitude. Tentons l'expérience tout de même. L'explication pourrait être plurielle.

Les objectifs du millénaire pour le développement (OMD) doivent être atteints en 2015 soit d'ici quelques mois. Il est évident que nombre de pays, notamment ceux de l'Afrique subsaharienne, ne seront pas au rendez-vous [1-3]. En effet ces pays parmi les plus vulnérables font face à une multiplication des priorités de santé. Aux maladies infantomaternelles, parasitaires et transmissibles s'ajoutent les pathologies non transmissibles. Parmi ces affections chroniques, les cancers pèsent d'un poids important [4]. Ce fardeau est responsable, en 2008, de 541800 décès. L'incidence est aussi en régulière augmentation et se situe à 715600 nouveaux cas dont 325000 hommes et 390000 femmes [4-6].

Le profil épidémiologique est caractérisé par une mortalité très élevée ( $78 \%$ des cas) et par une détection trop tardive de la maladie annihilant ainsi toutes possibilités thérapeutiques. Pourtant, les infections chroniques sont parmi les facteurs étiologiques les plus fréquents et les plus évitables (sida, hépatites $B$ et $C$, inflammations gastriques chroniques, etc.). Elles induisent environ $30 \%$ des cas de tumeurs malignes [5-7].

Que dire des perspectives épidémiologiques des cancers en Afrique? Une aggravation de la situation actuelle qui pourrait aboutir à un doublement autant de l'incidence que de la mortalité est la réponse qui découle des études prospectives du Centre international de recherche sur le cancer (CIRC), l'agence spécialisée de l'Organisation mondiale de la santé (OMS) [5]. Ce tableau se complique d'une inquiétante faiblesse des systèmes de santé (absence de couverture maladie, accessibilité aux soins, manque de personnel spécialisé, etc.) qui fait que le défi cancéreux sera difficile à relever $[5,6]$. 
is the outcome from prospective studies by the International Agency for Research on Cancer (IARC), a specialist World Health Organization (WHO) Agency [5]. This clinical picture is complicated by worrying weaknesses in healthcare systems (lack of medical cover, accessibility to health care, lack of specialized personnel, etc.) all of which means that the challenge of cancer is difficult to overcome $[5,6]$.

To this end, new public health initiatives and strategies must be introduced. The African Journal of Cancer/Journal Africain $d u$ Cancer has been instrumental in this movement, from its creation, as a means of mass communication [8]. Our function is to make this epidemiological reality visible and to encourage the emergence of a plan of action in the refusal to accept death through cancer in Africa. This plan will put forward a realistic approach, i.e. a tailored program in the fight against tumour diseases with the knowledge that its effectiveness is closely linked to complying with the socioeconomic and cultural determinants of the populations. Pre-requisites are knowledge of the scale of the problem, identification of the basic needs and the definition of assessment criteria for the relevance of measures proposed.

In addition, it is clear that never ending and dedicated sums of money are made available, which are sufficient to meet needs, if a true fight against cancer on this continent is to be shown.

Moreover, efforts should be of a sub-regional scale, both regional and across regional. No individual area can cope on its own. Given the limited funds, the problems with the infrastructure and the marked lack of human resources in African countries, a united strategy against cancer is essential throughout the whole treatment process (prevention, treatment, research, training, etc.). The sharing of technical and scientific tools and medical, managerial and financial expertise is an essential approach that will ensure that the actions are not only efficient but also sustainable.

With epidemiological mutations spreading across the African continent, more resources in this fight against cancer and a new type of partnership with developed countries are required. The $J A C$ is involved in the various aspects of promoting and sharing resources between healthcare stakeholders in Northern and Southern countries [5,9-11]. It also plays a fundamental linking role between specialists from developing countries $[6,12,13]$. Apart from some disparities, the genetic and environmental risks and the risk of infection are so similar throughout the continent that it is better to implement integrated anti-cancer programs and in a more widespread way against non-communicable diseases $[4,9,14]$.

These issues are so important that they have had an impact on both policy decision makers and large international institutions. Thus, the assembly of the United Nations (UN) had a high level summit in New York (USA) on non-communicable diseases and which resulted in a Political Declaration
Dans ce contexte, de nouvelles initiatives et stratégies de santé publique doivent être promues. Le Journal Africain $\mathrm{du}$ Cancer/African Journal of Cancer s'est inscrit dans cette mouvance dès sa création en tant qu'organe de diffusion [8]. Notre raison d'être est de rendre visible cette réalité épidémiologique et de susciter l'émergence d'un front pour le refus de la fatalité du cancer en Afrique. Il s'agit de proposer une réponse réaliste, c'est-à-dire un programme adapté de lutte contre les maladies tumorales dont on sait que les conditions d'efficacité sont étroitement liées aux respects des déterminants socioéconomiques et culturels des populations. Les préalables restent la connaissance de l'ampleur du problème, l'identification des besoins fondamentaux et la définition de critères d'évaluation de la pertinence des mesures proposées.

De surcroît, il est clair que des financements dédiés, disponibles et à la bonne hauteur des nécessités ne peuvent faire défaut si une réelle volonté de lutte contre le cancer sur le continent est affichée.

C'est ainsi que les efforts doivent être de dimensions sous-régionales, régionales d'une part et transversales de l'autre. Aucun état isolé ne pourra se suffire à lui-même. Compte tenu des limites financières, de l'indigence des infrastructures et du déficit prononcé en ressources humaines des pays africains, une stratégie unioniste contre les cancers s'impose tout au long des processus d'intervention (prévention, thérapie, recherche, formation, etc.). La mise en commun d'outils technicoscientifiques et d'expertises médicale, managériale, et financière est une approche salvatrice qui faciliterait la durabilité des actions et leur efficience.

Les mutations épidémiologiques en cours sur le continent africain exigent un renforcement des capacités de lutte anticancéreuse et un nouveau type de partenariat avec les pays développés. Le JAC est partie prenante dans ces divers aspects de la promotion et de la mutualisation des capacités entre les acteurs de santé des pays du Nord et du Sud [5,911]. Ce rôle primordial de passerelle nous le jouons aussi entre les spécialistes des pays en développement $[6,12,13]$. Hormis certaines disparités, les risques infectieux, génétiques et environnementaux sont si similaires à l'échelle $d u$ continent qu'il est plus fécond de mettre en cuvre des programmes intégrés de lutte contre le cancer et de façon plus élargie contre les maladies non transmissibles [4,9,14].

Ces enjeux sont d'une urgence telle qu'ils se sont imposés aux décideurs politiques et aux grandes institutions internationales. Ainsi, l'assemblée de l'Organisation des Nations unies (ONU) a tenu un sommet de haut niveau à New York (États-Unis) sur les maladies non transmissibles et négligées à l'issue duquel une déclaration politique a été adoptée. Elle enjoint tous les états membres à appliquer les directives pour la prévention et la maitrise des maladies non transmissibles de l'OMS [15,15a]. Rappelons que les OMD de la santé avaient complètement occulté la problématique du cancer et 
being approved. This requires that all Member States apply Directives for the prevention and control of WHO noncommunicable diseases $[15,15 \mathrm{a}]$. It should be noted that the health MDGs had totally hidden the problem of cancer and non-communicable diseases [1-3]. With regards to the African Union (AU), the meeting of Healthcare ministers during the $6^{\text {th }}$ ordinary session in Addis Ababa, Ethiopia focused on supporting a series of measures to reduce the problem of cancer and the impact of non-communicable diseases in the development of Africa [4a]. These political declarations and commitments have been beneficial in mobilizing and drawing attention towards these crucial public health matters. There is no doubt that if the effect of these declarations are seen, then they could provide the necessary legal and financial infrastructure to control the progress of cancer.

Furthermore, our strong commitment to these new heath challenges through the $J A C$ is made easier by the mutual trust that has been established between the Springer-Verlag France and Afrocancer Publications. Springer's internationally recognized expertise in scientific and medical publishing has enabled us to produce a quality review, entirely dedicated to the study of cancer. The professionalism of the teams concerned have earned us recognition and references for the journal in the largest databases in our sector [16].

In addition, due to the regularity of the publication and our hard work we were awarded a prize in the category of «Best information or reflective editorial» by the French Health Care Professions Press and Editing Union in 2011 [17]. In just a few years, the $J A C$ has earned a reputation for toughness and respect in areas of ethics and ethical standards from healthcare professional and the university hospital sector. This is also a way of measuring the quality of our work, and one to which we attach a great deal of importance. Nevertheless, from these successes, clear-thinking has led us to consider the financial aspects, without which a review, however useful and critically acclaimed, cannot survive. Although there are numerous and diverse submissions of articles, and now covering the whole continent, subscriptions have not followed suit. Added to this, economic conditions and market competition means that advertisers, especially from pharmaceutical companies, remain cautious. Our future challenges are therefore to become more visible and more attractive. As we strive for excellence, we will never stop improving both the content and the layout of our journal. It is a specific appeal that we are launching to accompany and maintain the necessary restructuring of $J A C$ that became e-only at the end of last year.

Finally and above all, rapid demographic, economic, social and environmental transformations that are happening across the African continent will have worrying consequences in terms of public health. Because the population of Sub-Saharan Africa is set to grow between now and 2050 des maladies non transmissibles [1-3]. Quant à l'Union Africaine (UA), la conférence des ministères de la Santé lors de sa $6^{e}$ session ordinaire à Addis-Abeba en Éthiopie s'est engagée à soutenir une série de mesures pour réduire la menace $d u$ cancer et l'impact des maladies non transmissibles et négligées dans le développement de l'Afrique [4a]. Ces déclarations et engagements politiques ont le bénéfice d'être mobilisateurs et d'attirer l'attention sur ces aspects cruciaux de santé publique. Nul doute que, s'ils sont suivis d'effets, ils pourraient fournir les structures juridiques et financières requises pour le contrôle de la progression des cancers.

Par ailleurs, notre forte implication dans ces nouveaux défis de santé à travers le JAC est facilitée par la confiance réciproque établie entre les Éditions Springer-Verlag France et Afrocancer. L'expertise internationalement reconnue de Springer dans l'édition scientifique et médicale nous permet d'avoir une revue de qualité entièrement dédiée à la cancérologie. Le professionnalisme des équipes concernées nous a valu la reconnaissance et le référencement du journal dans les plus grandes bases de données de notre secteur d'activité [16].

En addition, la sanction de la régularité de nos parutions et de notre travail acharné a été l'attribution d'un prix dans la catégorie "Meilleur éditorial d'information ou de réflexion » par le Syndicat de la Presse et de l'Édition des Professions de Santé (SPEPS) en 2011 [17]. En quelques années, le JAC s'est forgé une réputation de rigueur et de respect d'une certaine déontologie et de règles éthiques auprès des professionnels de santé et du milieu hospitalo-universitaire. Ceci est aussi un instrument de mesure de la qualité de notre travail auquel nous accordons une importance capitale. Néanmoins, notre lucidité nous conduit, au-delà de ces succès, à considérer les aspects financiers sans lesquels une revue, même utile et plébiscitée, ne peut vivre. Si les soumissions d'articles sont nombreuses, diversifiées et couvrent désormais l'étendue du continent, les abonnements ne suivent pas encore. Il s'y ajoute que la conjoncture économique et la compétitivité du marché font que les annonceurs, notamment les industries pharmaceutiques, restent frileuses. Nos challenges futurs seront donc d'être plus visibles et plus attractifs. Comme nous ciblons l'excellence, nous n'aurons de cesse d'améliorer autant le fond que la forme de notre journal. C'est un appel explicite que nous lançons pour accompagner et soutenir ces indispensables restructurations du JAC devenu e-only depuis l'année dernière.

Enfin et surtout, les transformations démographiques, économiques, sociales et environnementales rapides que subit le continent africain auront des conséquences redoutées en terme de santé publique. En effet, la population de l'Afrique subsaharienne croîtra, d'ici à 2050, de 850 millions à 1, 8 milliard d'habitants soit la moitié de l'augmen- 
from 850 million to 1.8 billion inhabitants, which is half the increase in the world-wide population that will itself go from 7 to 9 billion human beings. Furthermore, the acceleration in urbanization will result in a three-fold increase in populations living in towns, which will grow from 350 million to 1.1 billion people [18]. The declared Malthusian catastrophe would appear to be unlikely, while the problem of health care priorities, especially those of chronic and noncommunicable diseases, is already well anticipated $[14,19,20]$.

In conclusion, the Millennium Development Goals for 2015 will not be achieved. And neither will those that go beyond 2015. An honest review of the repeated failure of programs for Africa is the first of the conditions that needs to be addressed when heading towards a positive future. A clean break from outdated practices and organizations should then follow. Those which weigh down the present and could hinder or threaten the future, not ours, but that of future generations. To re-ignite interest after this discontentment will not be an easy task. However $4 \mathrm{P}$ medicine (prevention, prediction, personalization and participation) is not so far away that African people, in their lifetime, will not be able to achieve it.

\section{Acknowledgements}

The author would like to extend his thanks to Mrs Khadidja Kourouma, Administration of exhibitions at the Cité des sciences et de l'industrie in Paris, for her assistance and for supplying the human resources and documents.

Conflict of Interest: Adama Ly does not have any conflict of interest to declare.

\section{References}

1. http://www.un.org/fr/millenniumgoals/ (consulté le 19 octobre 2013)

2. http://www.unicef.org/french/mdg/ (consulté le 19 octobre 2013)

3. ONU (Organisation des Nations unies) (2012) Rapport sur les Objectifs du Millénaire pour le développement 2012. New York

4. Ly A, Khayat D (2007) Le cancer en Afrique. De l'épidémiologie aux applications et perspectives de la recherche biomédicale. Préface du Pr. Jean Dausset Prix Nobel de médecine, Édition INCA (Institut National du Cancer)

4a. Union Africaine (2013) Rapport sur le cancer en Afrique. Conférence des ministres de la santé de l'Union Africaine (CAMH6) Sixième session ordinaire, 22-26 avril 2013, Addis-Abeba (Éthiopie), CAMH/Exp/6(VI) ii, 23 pages

5. Sylla BS, Wild CP (2012) Cancer burden in Africa in 2030: Invest today and save tomorrow. J Afr Cancer 4:1-2

6. Sambo LG, Dangou JM, Adebamowo C, et al (2012) Cancer in Africa: a preventable public health crisis. J Afr Cancer 4:127-36

7. Ly A (2011) Enjeux et perspectives de la prévention des cancers dans les pays en développement. J Afr Cancer 3:268-72

8. Ly A (2009) Progression des cancers en Afrique. J Afr Cancer 1:1-3

9. McCarthy M, Maher D, Ly A, Ako Ndip A (2010) Developing the agenda for European Union collaboration on non-communicable diseases research in Sub-Saharan Africa. Health Research Policy and Systems 8:13 tation de la population mondiale qui passera elle-même de 7 à 9 milliards d'êtres humains. De plus, l'accélération de l'urbanisation provoquera un triplement de la population des villes qui évoluera de 350 millions à 1,1 milliard de personnes [18]. Le péril malthusien annoncé paraît improbable alors que l'augmentation prévue des priorités de santé notamment celles relatives aux maladies chroniques et non transmissibles est, quant à elle, déjà là [14,19,20].

Au total, les objectifs du millénaire pour le développement de 2015 ne seront pas atteints. Puissent ceux de post-2015 l'être. Un examen sans complaisances des causes des échecs répétés des programmes pour l'Afrique est la première des conditions pour aller vers un futur souhaitable. Devra suivre une rupture assumée avec les habitudes et organisations obsolètes. Celles qui lestent le présent et pourraient menacer ou hypothéquer le futur, pas le nôtre, celui des générations à venir. Réenchanter le désenchantement ne sera pas une chose aisée. Mais la médecine à $4 P$ (prévention, prédiction, personnalisation et participation) n'est pas ce lointain horizon que les peuples africains, de leur existence ou par essence, ne pourront pas atteindre.

\section{Remerciements}

L'auteur tient à témoigner sa gratitude à Madame Khadidja Kourouma, Direction des expositions de la Cité des sciences et de l'industrie de Paris pour son assistance et pour les ressources humaines et documentaires fournies.

Conflit d'intérêt : Adama Ly déclare ne pas avoir de conflit d'intérêt.

10. Perrier Bonnet S, de Thé G (2009) L'Alliance mondiale contre le cancer. J Afr Cancer 1:61-3

11. Godet J, Keller MR (2009) Pour une mobilisation générale. J Afr Cancer 1:253-5

12. Ly M, Ly A, Rodrigues M, et al (2010) Le cancer en Afrique, un nouveau défi sanitaire. Exemple du Mali et de l'association Oncomali. Bull Cancer 97:965-8

13. Catalfamo Akbaraly C, Allegri C (2013) Fondation Akbaraly. J Afr Cancer 5:185-8

14. Ly A (2012) Cancers et autres maladies non transmissibles : vers une approche intégrée de santé publique. J Afr Cancer 4:137-9

15. http://www.un.org/News/fr-press/docs/2011/AG11138.doc.htm (consulté le 19 octobre 2013)

15a.http://www.who.int/mediacentre/news/notes/2012/ncd_20121109/ fr/ (consulté le 19 octobre 2013)

16. www.springer.com $/ 12558$

17. Robert J (2011) Vers une prescription individualisée des traitements anticancéreux. J Afr Cancer 3:1-2

18. FNUAP (Fonds des Nations unies pour la population) (2012) État de la population mondiale 2012. Oui au choix, non au hasard : planification familiale, droits de la personne et développement. New York

19. PNUD (2012) Rapport sur le développement humain en Afrique 2012 : Vers une sécurité alimentaire durable. New York

20. PNUD (2013) Rapport sur le développement humain 2013: L'essor du Sud : Les progrès humains dans un monde diversifié. New York 